\title{
Inbuilt Characteristics of Hydrolytic Enzymes Activities in Root Tissues of Chickpea (Cicer arietinum L) Cultivars of Gujarat against Fusarium Wilt (Fusarium oxysporium f.spp ciceri) Disease Infection
}

\author{
P. J. Rathod ${ }^{1 *}$ and D. N. Vakharia ${ }^{2}$ \\ Department of Biochemistry, College of Agriculture \\ Junagadh Agricultural University, Junagadh-362001 (Gujarat) India \\ *Corresponding author
}

\begin{tabular}{l} 
Ke y w o r d s \\
$\begin{array}{l}\beta-1,3-\text { glucanase, } \\
\text { Chitinase, Chickpea }\end{array}$ \\
Article Info \\
$\begin{array}{l}\text { Accepted: } \\
18 \text { May } 2020 \\
\text { Available Online: } \\
10 \text { June } 2020\end{array}$ \\
\hline
\end{tabular}

A B S T R A C T

\begin{abstract}
A field experiment was conducted In Sick plot of Pulse research station, JAU., Junagadh. To find out the genetic makeup of hydrolytic enzymes of six chickpea cultivars that was grown in normal (healthy soil) and sick plot (Diseased soil) in response to wilt disease. The pattern of theses enzymes showed The $\beta-1,3-$ glucanase revealed that the significantly higher activity as the growth of plants and as the disease development, Plants grown in sick plot, the $\beta-1,3$-glucanase activity in the different cultivars were varied between 89.02 to $368.42 \mu$ mole glucose released.h-1.g-1.fr.wt. Susceptible cultivar JG-62 and GG-4 had significantly higher activity, than resistant and tolerant cultivars. Similarly In case of chitinase activity resulted significant differences in our experiments. The root tissues obtained from sick plot visualized higher chitinase activity as compared to the tissues received from normal plot. Among the cultivars, susceptible cultivars have similar trend as observed in $\beta-1,3$-glucanase. Lower level of the enzyme activity in root tissues was observed in tolerant cultivars. Thus hypothesis on the basis of fungal invasion is also proved by hydrolytic enzymes and its can be classified as GG-1(tolerant), GG-2 (Tolerant), JG-62 (Highly susceptible), JCP27, WR-315, (Highly Resistant) and GG-4 (Susceptible) to fusarium. It can be concluded that both $\beta$-1, 3-glucanase and chitinase activity having defensive role thus it can be used as biochemical marker for identification of fungal resistant cultivars.
\end{abstract}

\section{Introduction}

Chickpea (Cicer arietinum L.) is the second most important pulse crop of the world. India is the world's largest chickpea growing country having contributes about 63 percent to the global production of chickpea. Gujarat having cultivation area of 0.17 lakh hectares and an output of 0.09 metric tonnes with yield $530 \mathrm{~kg} / \mathrm{ha}$ in 2000-01(Anon, 2003). Now it is not much change in yield. 
Chick pea flour (besan) is an ingredient in various types of sweets and bhajiya. Chick pea is also having medicinal effects for blood purification. Its nutritional composition varies with varieties but averages are 21.1-22.8 per cent protein, 55-61.5 per cent carbohydrates,3- 4.5 per cent fat. Chickpea is rich in calcium, iron and niacin. ( Rathod and Vakhariya, 2008) so far as In a data of the resequencing of 429 chickpea accessions from 45 countries identified key candidate genes that were under selection and those associated with agronomically important traits (Varshney et al., 2019) . Numerous approaches are taken from world scientist on crop improvements from genomics, proteomics, transcriptomics, as well as in recently suggested novel approach called "super-pangenome", which includes the development of pangenome or pangenomes of different species in a given genus, provides an opportunity to identify genus-level genomic variation (Khan et al., 2020). But without the Fundamental knowledge of enzymes works on pathogen and activities differ in different condition are very crucial to give most imperative wrapping up in given experiments. So Author has tried to justify the activities of both enzymes during inflectional, and normal condition in chickpea.

Wilt of chickpea (Cicer arietinum), caused by Fusarium oxysporum f. sp. ciceris is a major limiting factor of chickpea production in the Mediterranean Basin and the Indian Subcontinent (Jalali and Chand, 1992). Annual yield losses due to Fusarium oxysporum. f.sp. ciceri have been epidemics and devastating to individual crops and cause $100 \%$ loss under favorable conditions (Halila and Strange, 1996; Chaube and Pundhir, 2005). Defense reaction of the plant that is related to the mechanisms of cell wall modification is the rapid formation of papillae-localized appositions of dense material between the plasmalemma and the cell wall at the penetration site of the pathogen. They are composed of cross-linked proteins, phenolic compounds and callose, (Heitefuss, 1997). $\beta$-1,3-glucanase enzymes that act on other substrates present in the cell wall include invertase, peroxidase, phosphatase and various dehydrogenases.

Enzymes with potential activity against fungal pathogens include chitinases and $\beta-1,3-$ glucanases (Cosgrove, 1997). Since the accumulation of PR-proteins and cell wall enforcement by oxidative cross-linking of structural proteins and the formation of papillae have been documented in the interaction between $F$. graminearum and wheat (Pritsch et al., 2000; Pritsch et al., 2001; El-gendy et al., 2001; Kang and Buchenauer, 2003), fungal proteases are almost certainly part of the interaction between the pathogen and the host. Therefore the present enzymes $\beta$-1, 3-glucanases and chitinase were examined biochemically to elucidate the changes in enzyme activities in various growth stages as well as to prove hypothesis of design of experiments in various cultivars for better used in predicted off climate situations.

\section{Materials and Methods}

Field experiments was conducted with the experimental design of split plot at Pulse research station, Junagadh Agricultural University Junagadh., Gujarat India. Two different separate plots as main factors, Three different stages were (preinfectional, inflectional and post inflectional stages) ,Varieties as split factors in both plots, in which the Chickpea cultivars GG-1(tolerant), GG-2 (Tolerant), JG-62 (Highly susceptible), JCP-27, WR-315, (Highly Resistant) and GG4 (Susceptible), were grown under field condition in two plots. One plot was i.e normal plot (Helathy) without diseased while other was kept free for infection of wilt 
disease in chickpea plants i.e, Sick plot (Diseased plot) that is maintaining, since 28 years for F.oxysporium f.sp.ciceri with appropriate inoculation and tested for diseased infection in the seasons as well as use for AICRP trial too. Root tissues were harvested with preconditioning of tap water and cleaning effects at pre infectional (12 Days after sowing), infectional (21 days after sowing) and post infectional (26 Days after sowing) stage from both plots. Sample was preserve in $-80^{\circ} \mathrm{C}$ until analysis is over.

\section{Extraction and assay of activity $\beta-1-3$ glucanase (EC 3.2.1.16)}

The enzymes $\beta-1-3$ glucanase were estimated using the method suggested by Malik and Singh (1980). Kauffman et al., (1987) and Nelson (1944). Weigh one gram root tissue grind with $10 \mathrm{ml}$ of $0.1 \mathrm{M}$ sodium Acetate $\mathrm{pH}$ 4.8 addition with $15 \mathrm{mM}$ Mercapto ethanol,1mM PMSF. Centrifuged to 10000 rpm, $15 \mathrm{~min},-4^{0} \mathrm{C}$. As a substrate laminarin was used. Assay mixture consists of $0.4 \mathrm{ml}$ $0.1 \mathrm{M}$ sodium Acetate buffer $\mathrm{pH} 4.8$ with 2.5 $\mathrm{mg}$ laminarin. To initiate reaction $0.5 \mathrm{ml}$ Enzyme with assay mixture incubates temperature at $37^{\circ} \mathrm{C}$ for 2hour. Glucose releases per hour which was measured Spectrophotometrical at $660 \mathrm{~nm}$. Enzyme activity expressed in $\mu$ mole glucose released/h/g.

\section{Extraction and Assay of activity for Chitinase assay (EC 3.2.1.14)}

Determination of $\mathrm{N}$ - acetylglucosamine: (for Chitinase assay): The enzymes chitinase were estimated using the method suggested by (Boller and Mauch ,1988; Reissig et al., 1955). Suitable aliquot $(0.5 \mathrm{ml})$ after incubation was taken in to test tubes and 0.1 $\mathrm{ml} 0.12 \mathrm{M}$ potassium borate buffer $\mathrm{pH} 8.9$ was added. The tubes were kept in boiling water bath exactly for 3 min and cooled in tap water. Three ml DMAB (10 g DMAB was dissolved in $1000 \mathrm{ml}$ glacial acetic acid (AR) which contains $12.5 \%$ v/v $10 \mathrm{~N} \mathrm{HCl}$ (AR). It was stored at $2^{0} \mathrm{C}$ as a stock prior to use before it was diluted with nine volume of glacial acetic acid.) was added in each tube and incubated at $38^{\circ} \mathrm{C}$ for 20 minutes. Tubes were cooled and absorbance was measured at $544 \mathrm{~nm}$ in spectrophotometer. Standard Nacetylglucosamine in the range of 0.05 to 0.30 $\mu$ mole was prepared in borate buffer and was calibrated by following the above procedure.

\section{Results and Discussion}

\section{$\beta$-1,3-glucanases}

Chickpea cultivars grown in normal and sick plots showed significant difference in root $\beta$ 1,3-glucanase activity. The root tissues were obtained from sick plot contained lower $\beta-1,3$ glucanase activity as compared to the tissues received from normal plot (Fig.1). Cultivars differed significantly in their B-1-3 glucanase activities. Among the cultivars, susceptible cultivars JG-62 and GG-4 showed significantly higher $\beta$-1, 3-glucanase activity as compared to the resistant cultivars (WR315 and JCP-27) and tolerant cultivars (GG-1 and GG-2). However tolerant cultivars $\mathrm{V}_{3}$ contained significantly lower level of enzyme activity in root tissue. (Fig.1) Among the different infectional stages, the $\beta-1,3$ glucanase activity increased from 86.55 to $225.84 \mu$ mole glucose release. $\mathrm{h}^{-1}$. $\mathrm{g}^{-1}$.fr.wt. with the advancement of disease and growth of plants. The enzyme activity drastically increased at infectional stage (S2) and it was more pronounced at post infectional stage (S3). Data showed increasing trend of activity of the enzyme in root tissues from $S_{1}$ to $S_{3}$ stage, in general.

Plants grown in sick plot, the $\beta-1,3-$ glucanase activity in the different cultivars were varied between 89.02 to $368.42 \mu$ mole 
glucose released. $\mathrm{h}^{-1} \cdot \mathrm{g}^{-1}$.fr.wt. Susceptible cultivar JG-62 and GG-4 had significantly higher activity, resistant and tolerant cultivars had lower activity as compared to susceptible cultivars grown in sick plot. Plants grown in normal plot, similar trend as recorded in sick plot. Healthy plant tissues from normal plot displayed significantly higher enzyme activity in JG-62 as compared to cultivars grown in sick plot. Cultivars contained almost similar values in enzyme activity recorded for resistant and tolerant cultivars grown in normal plots but wide variation in the enzyme activity was seen in sick plot. In general, plants grown in normal plot showed higher activity of enzyme as compared to the plants from sick plot and it was varied between 200.9 to $382.19 \mu$ mole glucose released. $h^{-1} . \mathrm{g}$ ${ }^{1}$.fr.wt. Our data received for $\beta$-1, 3-glucase activity are in agreement with Naik et al.,(2005) who revealed that the increase in activity of $\beta$-1, 3-glucase in both susceptible and resistant lines against fusarium wilt.

Irrespective of plots (treatments), at preinfectional stage $\left(\mathrm{S}_{1}\right)$, resistant (WR-315 and JCP-27) and tolerant (GG-1 and GG-2) cultivars resulted significantly higher $\beta-1,3$ glucanase activity than the susceptible cultivars JG-62 and GG-4. The tolerant cultivar GG-2 contained the significantly highest activity i.e $96.26 \mu$ mole glucose release. $\mathrm{h}^{-1} \cdot \mathrm{g}^{-1}$.fr.wt. at pre infectional stage (S1) the activity was continued to rise in all the cultivars from pre infectional $\left(S_{1}\right)$ to post infectional stage $\left(S_{3}\right)$. However by this stage, the susceptible cultivars JG-62 and GG-4 showed significantly remarkably higher activity than the resistant and tolerant cultivars. In general, the trend of enzyme activity increased as progress of plant growth and development of tissues.

Interaction effect of $\mathrm{TxVxS}$ of $\beta-1,3-$ glucanase activity revealed significant difference in root tissues. (Fig. 2). Plant grown in sick plot resulted significant change in response to disease infection in root tissues of all the six cultivars. Susceptible cultivars JG-62 and GG-4 showed the highest $\beta-1-3$ glucanase activity at all stages of infection in tolerant and resistant cultivars. At infectional stages, all the cultivars had remarkably higher activity. Susceptible cultivars JG-62 and GG4 visualized appreciable change in $\beta-1-3$ glucanase from infectional $\left(\mathrm{S}_{2}\right)$ to post infectional stage $\left(\mathrm{S}_{3}\right)$.

The activity of enzyme was declined in resistant and tolerant cultivars at post infectional stage except in JCP-27, where the activity was increased. Changes among the severity of diseases development and activity correlate at this stage showed significant cultivars differences in root tissues except in JCP-27. Susceptible cultivar had the significantly highest $\beta$-1,3-glucanase activity as compared to tolerant cultivars and, resistant cultivars (WR-315 and JCP-27) at infectional stage $\left(\mathrm{S}_{2}\right)$ with the advancement of diseases. At post infectional stage $\left(\mathrm{S}_{3}\right) \mathrm{JG}-62$ and GG-4 had the significantly highest $\beta-1-3$ glucanase activity as compared to other cultivars grown in sick plots.

In case of plants from normal plot, cultivars grown in healthy soil increasing trend of $\beta-1$ 3 glucanase activity as progress or growth of the plants from $S_{1}$ to $S_{3}$. The activity drastically increased from $S_{1}$ to $S_{3}$ in all the cultivars. However, differences were greater in susceptible cultivars JG-62 and GG-4. Overall data recorded for $\beta$-1, 3-glucanase activity are supported by Thangavelu et al., (2003), Saika et al., (2005). Ramamoorthy et al.,(2002) revealed that the activity of beta 1,3 glucanase and chitinase were induced to accumulate at higher levels at 3-5 days of challenge inoculation in bacterized plants of banana with Pseudomonas fluorescens isolate PF1. 


\section{Chitinase}

The fungal chitinases was consist of five different domains: (a) N-terminal signal peptide region, (b) catalytic domain, (c) chitin-binding domain, (d) serine/theonine rich-region, and (e) C-terminal, (Dean et al,2012) It also possess specific affinity towards polymer chitin to degrade it into lowmolecular-weight COS (chitooligosaccharides) and GlcNAc (Nacetylglucosamine). Chickpea cultivars grown in normal and sick plots had resulted significant difference in root chitinase activity. The root tissues obtained from sick plot visualized higher chitinase activity $(0.72$ n.mole N-acetyl glucosamine. $\mathrm{h}^{-1} \cdot \mathrm{g}^{-1}$.fr.wt) as compared to the tissues received from normal plot (0.57n.mole acetyl glucosamine.h-1.g1.fr.wt). Fig.3. Among the cultivars, susceptible cultivars JG-62 and GG-4 showed significantly higher chitinase activity as compared to the resistant cultivars JCP-27 and WR-315 and tolerant cultivars GG-1 and GG-2. Lower level of the enzyme activity in root tissues was observed in tolerant cultivars (Fig.3). Chitinases have been implicated more

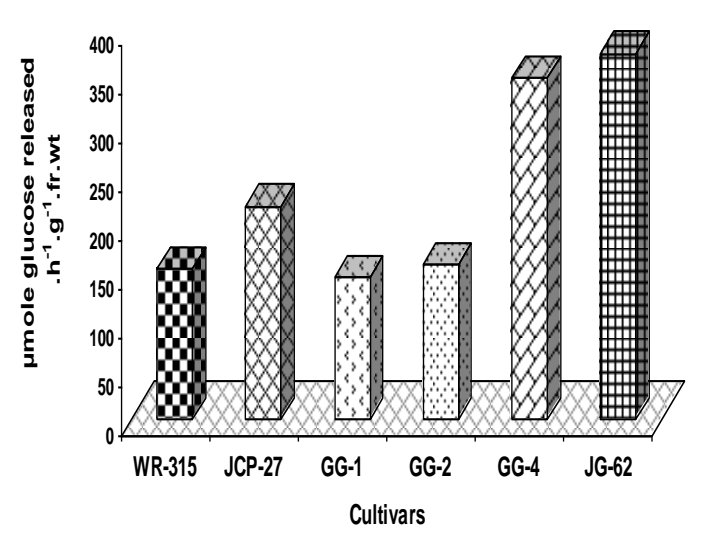

in the plant defense mechanism (Vanloon, 1985; Schlumbaum et al.,1986; Linthrost et al., 1991). It is known that chitinases degrade chitin in fungal cell wall (Schlumbaum et al.,1986) and also act synergistically with the $\beta-1,3$ glucanase for inhibiting fungal growth (Mauch et al.,1984). Among the different infectional stages, the activity increased from 0.63 to 0.87 n.mole $\mathrm{N}$-acetyl glucosamine. $\mathrm{h}^{-}$ ${ }^{1} . \mathrm{g}^{-1}$.fr.wt. with the advancement of disease and growth of plants i.e. pre-infectional stage $\left(\mathrm{S}_{1}\right)$ to post infectional stage $\left(\mathrm{S}_{3}\right)$. However the levels of chitinase activity significantly decreased at infectional stage $\left(\mathrm{S}_{2}\right) \quad(0.42$ n.mole N-acetyl glucosamine. $\mathrm{h}^{-1} \cdot \mathrm{g}^{-1}$.fr.wt) and increased remarkably at post infectional stage (S3) (0.87n.mole $\mathrm{N}$-acetyl glucosamine. $\mathrm{h}^{-1} \cdot \mathrm{g}^{-1}$ .fr.wt).

Chitinase activity in chickpea plants either grown in sick plot or normal plot did not show any significant change. In general plants grown in sick plot had little higher activity in all the cultivars as compared to the plants grown in normal plot. At pre infectional stage all the cultivars did not show any significant differences in their activity.

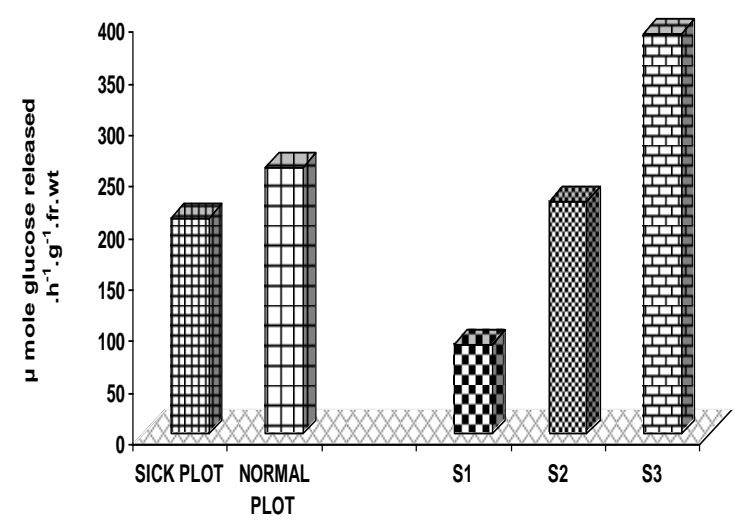

Fig.1 Mean effect of cultivars, treatments and stages on $\beta$-1,3-glucanase activity in chickpea root tissues. $S_{1}$-pre infectional stage; $S_{2}$-infectional stage; $S_{3}$-post infectional stage. $S . E m \pm 0.71$ (V), $0.41(\mathrm{~T}), 0.68(\mathrm{~S})$; C.D. at 5\%, $2.09(\mathrm{~V}), 1.21(\mathrm{~T}), 1.93(\mathrm{~S})$ 


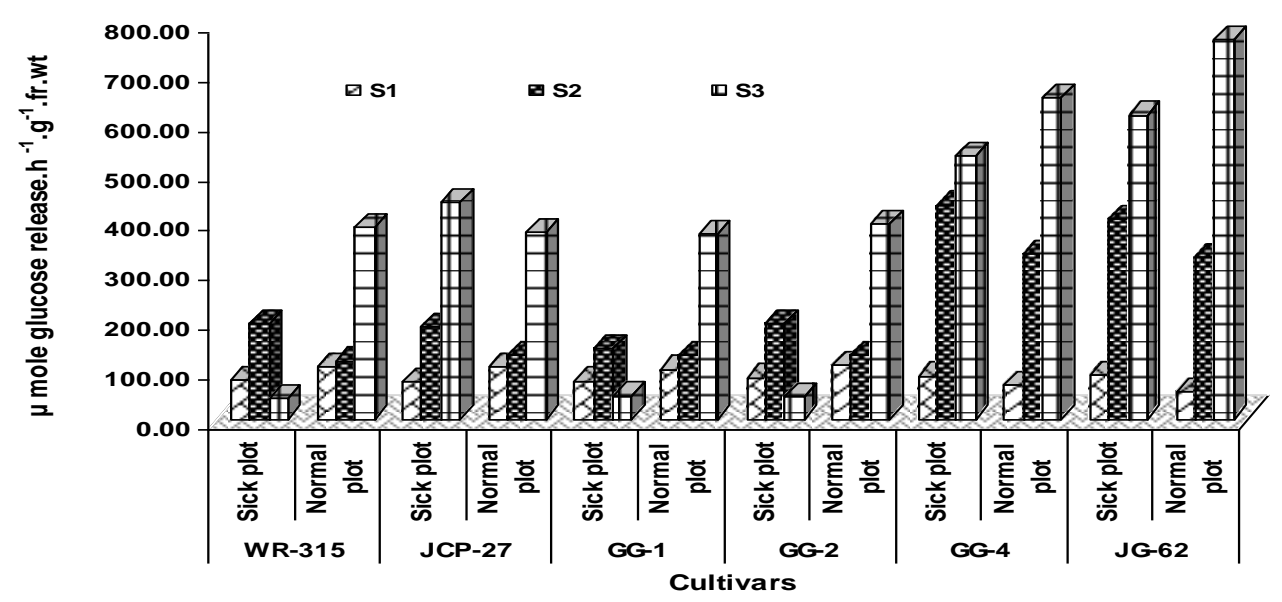

Fig.2 Interaction effect of TxVxS on $\beta$-1,3-glucanase activity in root tissues of chickpea cultivars. $\mathrm{S}_{1}$ - pre infectional stage; $\mathrm{S}_{2}$-infectional stage; $\mathrm{S}_{3}$-post infectional stage.

S.Em \pm 2.34 , C.D. at $5 \% 6.67$
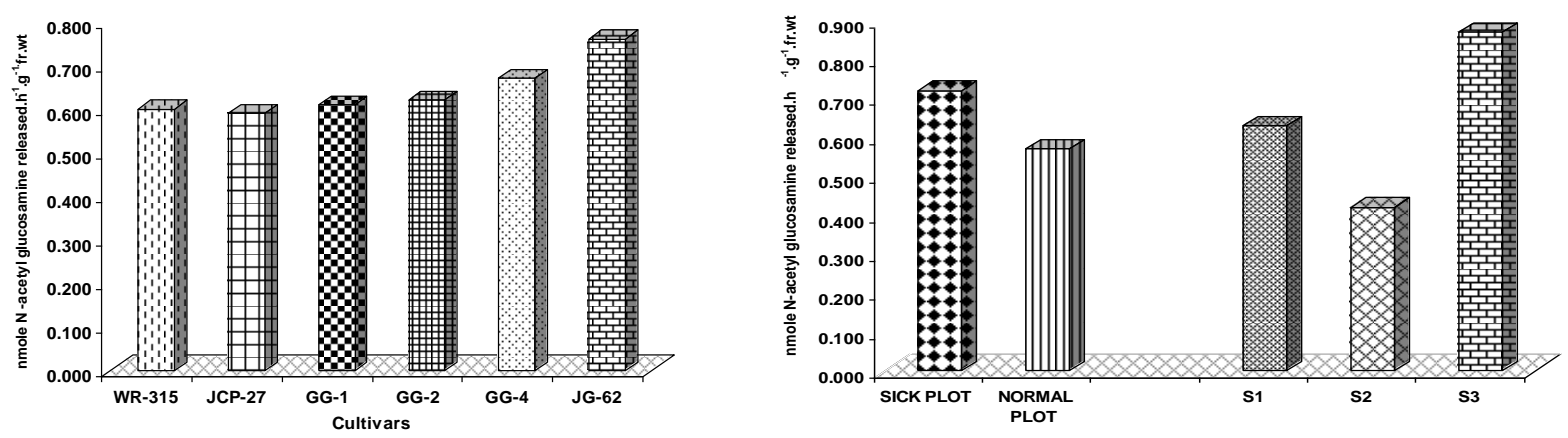

Fig.3 Mean effect of cultivars, treatments and stages on chitinase activity in chickpea root tissues. $\mathrm{S}_{1}$-pre infectional stage; $\mathrm{S}_{2}$-infectional stage; $\mathrm{S}_{3}$-post infectional stage. $\mathrm{S}$.Em $\pm 0.04(\mathrm{~V})$, 0.03 (T), 0.04 (S); C.D. at 5\%, NS (V), 0.08 (T), 0.11 (S)

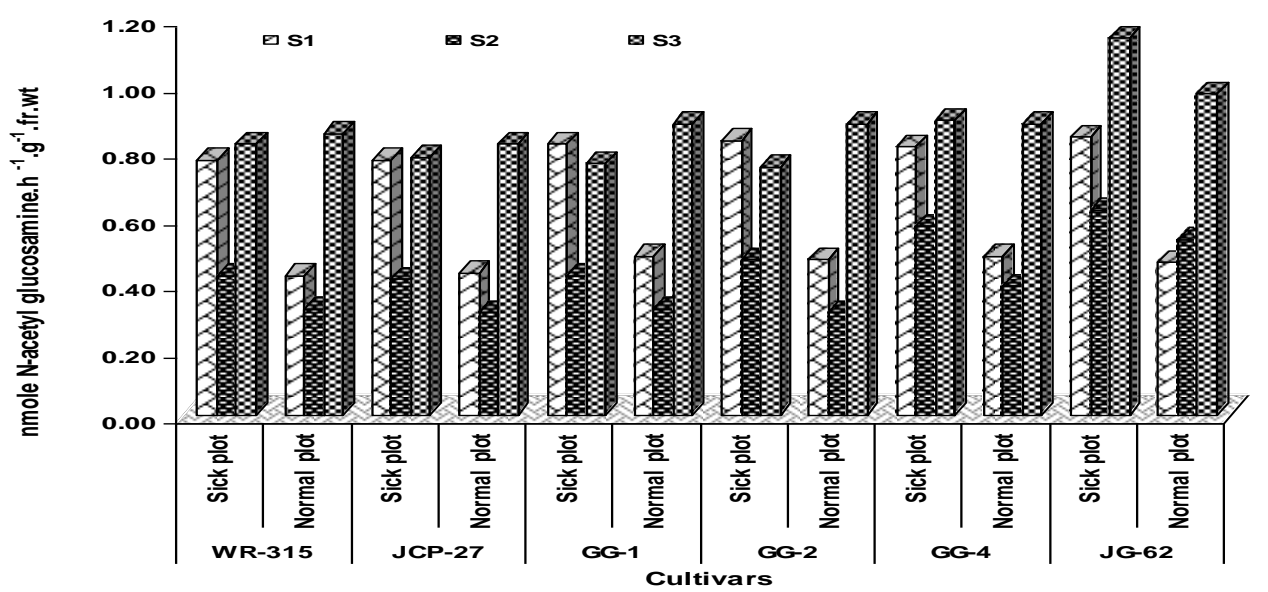

Fig.4 Interaction effect of TxVxS on chitinase activity in root tissues of chickpea cultivars. $\mathrm{S}_{1^{-}}$ pre infectionalstage; $\mathrm{S}_{2}$-infectional stage; $\mathrm{S}_{3}$-post infectional stage. $\mathrm{S} . \mathrm{Em} \pm 0.13$, C.D. at 5\% NS 


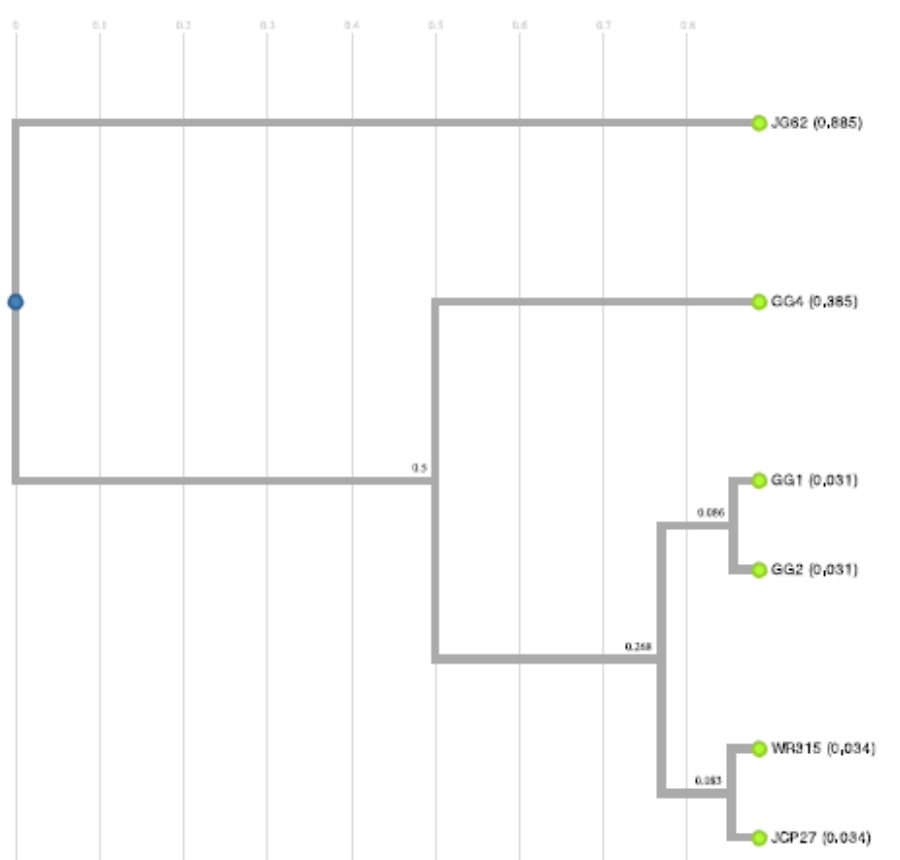

Figure.5 Chitinase dendrogramme of varietal differences among the varieties

The enzyme activity drastically declined at infectional stage $\left(S_{2}\right)$. However the reduction in chitinase activity was less in susceptible cultivars. At post infectional stage $\left(\mathrm{S}_{3}\right)$, again increased in all the cultivars. Saikia et al., (2005) revealed that the maximum activity of chitinase was recorded after three days of inoculation in all induced plant of chickpea. Thereafter, the activity decreased progressively. Two chitinases detected in induced chickpea plants infected with Fusarium oxysporum f. sp. ciceris.

Interaction effects of $\mathrm{Tx} V \mathrm{xS}$ did not revealed any significant differences in chitinase activity (Fig.4). Irrespective of plant grown in sick plot and normal plot, susceptible cultivars JG-62 and GG-4 had higher chitinase activity as compared to resistant cultivars at all the stages. The enzyme activity at infectional stage (S2) though the plants from normal plot had little higher value.

In general, chitinase activity in root tissues at infectional stage in sick plot (diseased plant) and normal plot (healthy plant) are in agreement with the published literature. In some plant species, resistant tissues accumulate chitinase more rapidly and at higher concentration than susceptible tissues (Benhamou et al.,1990; Hedrick et al.,1988; Irving and Kuc, 1990; Joosten et al., 1990; Rasumussen et al., 1992; Samac et al., 1990; Wyatt et al., 1990). In many of these tissues the resistance response was initially hypersensitive reaction with very rapid localized cell death (Hahlbrock et al., 1989 Vogeli et al., 1988; Voisey and Slusarenko, 1989).

Overall data reported for chitinase activity are in agreement with the findings suggested by Shukla (2001), Shukla and Suthar (2017). He examined chitinase activity in root tissues of resistant and susceptible cultivars of chickpea at different stages of infection in inoculated and uninoculated pot experiments. The results obtained in the field experiments are in agreement with data obtained by Cachinero et $a l .$, (2002) studied on plant defense reactions against fusarium wilt in chickpea induced by incompatible race 0 of Fusarium oxysporum 
f.sp. ciceri and nonhost isolates of $F$. oxysporum. This defense-related response was induced more consistently and intensely by non-host isolates of $F$. oxysporum than by incompatible FOC race 0 and the antifungal hydrolases,

Chitinase enzyme in healthy plats may be involved in elicitation reaction to activate plant defense mechanism. In case of disease infection, chitinase may also accumulate in response to fungal elicitors and participate in response to the elicitors and may take part in defense reaction by preventing further development of fungal pathogen. (Cachinero et al, 2002, Saika et al., 2005). Chitinase and $\beta$ 1-3, glucanase have been examined in present study but other enzymes capable of degrading hyphal cell wall are known to be present in higher plants. The possibility exists that host polysaccharides operating under specific conditions could provide an explanation for the lysis of vascular pathogens. The enzyme can either induce by infection with pathogens or treatment with the elicitors/chemicals (Bowles, 1990).

$\beta$-1,3-glucanase is another hydrolytic enzyme involved in degradation of fungal cell wall. The major products formed due to hydrolysis are oligomer $\beta$-1,3- glucans. There are large numbers of factors responsible for accumulation of this enzyme and lack of high degree of pathogen specificity in their induction implies that these are part of a general response of the plant stress. However their induction has correlated with greater resistance to subsequent pathogen attacks. Pattern of rising $\beta$-1,3-glucanase from infectional to post infectional stage same was true for healthy plants also with growth of the plants. $\beta$-1,3-glucanase is actively associated with during infection process as a part of disease resistance mechanism. As the fungi could not progress further the high level of activity was no longer persist in root tissues of resistant plants grown in sick plot. In infected plants there is continuous progress of fungi hence the high level of $\beta$-1,3-glucanase is always beneficial as a part of defense reaction to hydrolyse the fungal cell wall. The results of present investigation are supported to the findings of Naik et al., (2005); Thangavelu et al., (2003); Saika et al., (2005) and Ramamoorthy et al., (2002), (Rathod, 2008).

In conclusions, the results obtained in the field experiments are in agreement with previous findings and Interaction effect of $\mathrm{TxVxS}$ of $\beta$-1, 3-glucanase and chitinase activity revealed significant difference in root tissues infected with Fusarium oxysporum f.sp. ciceri grown in sick plot as well as in diseased tissues of all the six cultivars. It exhibits defensive reaction in susceptible and diseased plots and cultivars grown in healthy plot showed resistant and higher activities of the both enzymes under experimental condition thus its prove hypothesis of experimental design. It can be concluded that both $\beta$-1, 3-glucanase and chitinase activity having role in disease resistance and it can be biochemical marker for identification of fungal resistant cultivars.

\section{Conflict of interest}

There is no conflict of interest, it is part of $\mathrm{Ph} . \mathrm{D}$ research of junagadh Agricultural University thesis submitted and published some parts in some journals and books too.

\section{References}

Boller T and Mauch, F (1988). Colourimetric assay of chitinase methods. Enzymol.161:431-435.

Benhamou, N.; Joosten, M.H.A.J. and De Wit, P.J.G.M. (1990). Subcelluar localization of chitinase and of its potential substrate in tomato root tissues 
infected by Fusarium oxysporum f.sp radicis-lycopersici. Plant Physiol., 92:1108-1120.

Bol, J.F. (1991). Tobacco and tomato PR proteins homologus to win and pro Hevein Lack the "Hevein" domain. Mol. Plant. Microbe Interact., 4:586592.

Cachinero, J.M.; Hervas, A.; Jimenez-Diaz, R.M and Tena, M. (2002). Plant defence reactions against fusarium wilt in chickpea induced by incompatible race 0 of Fusarium oxysporum f.sp. ciceris and nonhost isolates of $F$. oxysporum. Plant-Pathology., 51: 765-776.

Chaube, H.S. and Pundhir, V.S. (2005). Crop diseases and their managementEdition-2005. Prentice Hall of India Pvt. Ltd. NewDelhi. Chapter-22 Vascular wilt. Pp 461

Dean, R.; Van Kan, J.A.; Pretorius, Z.A.; Hammond-Kosack, K.E.; Di Pietro, A.; Spanu, P.D.; Rudd, J.J.; Dickman, M.; Kahmann, R.; Ellis, J. (2012) The top 10 fungal pathogens in molecular plant pathology. Mol. Plant Pathol. 13, 414430

Halila, M.H. and Strange, R.N. (1996). Identification of the causal agent of wilt of chickpea in Tunisia as Fusarium oxysporum f.sp. ciceri race 0 . Phytopathol. Mediterr. 35:67-74.

Cosgrove, D.J. (1997). "Assembly and enlargement of the primary cell wall in plants."Annual Review of Cell and Developmental Biology. 13: $171-201$

El-Gendy, W.; Brownleader, M. D.; Ismail, H.; Clarke, P.J.; Gilbert, J.; El-Bordiny, F.; Trevan, M.; Hopkins, J.; Naldrett, M. and Jackson, P. (2001). "Rapid deposition of wheat cell wall structural proteins in response to Fusariumderived elicitors." Journal of Experimental Botany. 54: 85 - 90.

Heitefuss, R. (1997). Cell wall modifications in relation to resistance. Resistance of crop plant against fungi. H. Hartleb, Heitefuss, R. and Hoppe, H. H. Jena, Stuttgart, Lübeck, Gustav Fischer Verlag . pp 126

Hahlbrock, K.; Scheel, D.; Logemann, E.; Nurnberger, T.; Parniske, M.; Reinold, S.; Sacks, W.R and Schmelzer, E. (1989). Oligopeptide elicitor-mediated defense gene activation in cultured parsley cells. Proc.Natl.Acad.Sci.U.S.A. Washington, D.C. National Academy of Sciences, May 9, 1995. v. 92 (10) p. 4150-4157.

Hedrick,S.A.; Bell, J.N.; Boller, T. and Lamb, C.J. (1988). Chitinase cDNA clonning and mRNA induction by fungal elicitor, wounding and infection. Plant Physiology. 86:182-186.

Irving, H.R and Kuc, J.A. (1990). Local and systemic induction of peroxidase, chitinase and resistance in cucumber plants by K2HPO4.Physiol.Mol.Pl.Pathol.37:355 $-366$.

Jalali, B.L and Chand, H. (1992) Chickpea wilt. In: Singh US, Mukhopadhayay A.N, Kumar J, Chaube HS (eds) Plant diseases of international importance, vol 1 , diseases of cereals and pulses. Prentice Hall, Englewood CliVs, New York, pp 429-444.

Joosten, M.H.A.J.;Bergmans, C.J.B.; Meulenhoff, E.J.S.; Cornelissen, B.J.C and De.Wit, P.J.G.M. (1990). Purification and serological characterization of three basic $15 \mathrm{kD}$ pathogenesis related proteins from tomato. Plant physiol. 94:585-591.

Rathod , P.J (2008) Thesis submitted in Junagadh Agricultural University for doctoral degree (http://krishikosh.egranth.ac.in/bitstrea $\mathrm{m} / 1 / 77820 / 1 / \mathrm{JAU} \% 20-\% 201210 . p d f)$

Kang, Z. and Buchenauer, H. (2003). "Immunocytochemical localization of cell wall bound thionins and 
hydroxyproline-rich glycoproteins in Fusarium culmorum-infected wheat spikes." Journal of Phytopathology. 151: 120 - 129

Khan AW, Garg V, Roorkiwal M, Golicz AA, Edwards D, Varshney RK (2020) Super-pangenome by integrating the wild-side of a species for accelerated crop improvement. Trends Plant Sci. https://doi.org/10.1016/j.tplants.2019.10 .012

Linthrost, H.J.M.; Danhash,N.; Brederode, F.T.; Van Kan, J.A.L.; De. Wit, P.J.G.M.; and Kauffman,S., Legrand., Geoffroy,P and Fritig, B (1987). Biological functions of pathogenesis related proteins; Four PR proteins of Tobacco have $B$ 1-3 gulucanase activity, EMBO.J.6:3209-3212

Mauch, F.; Mauch-Mani, B and Boller, T. (1984). Anti fungal hydrolases in pea tissue.II. Inhibition of fungal growth by combination of chitinase and $\beta-1,3$ glucanase. Plant Physiol. 88.936-942

Malik, C. P. and Singh, S. P. (1980). "Plant enzymology and histoenzymology". Kalyani Publishers, Ludhiana. pp 54-56, 71-72.

Naik, R and Addy, S.K. (1973). Free amino acid changes in peanut foliage in relation to Cercospora leaf spot disease. Indian Phytopathology. 26: 245-248.

Nene, Y.L.; Haware, M.P.; Reddy, N.M.V.; Philps, J.P.; Castro E.L.; Kotasthane, S.R.; Gupta, O.; Singh, G.; Shukia, P and Sah, R.P. (1989). Identification of broad based and stable resistance to wilt and root-rots in chickpea. Indian Phytopathol., 42:499-505

Nelson, N (1944). A photometric adaptation of the somogyi method for the determination of glucose. J.Biol.Chem.153:375-380.

Pritsch, C., Muehlbauer, G. J., Bushnell, W. R., Somers, D. A. and Vance, C. P.(2000). "Fungal development and induction of defense response genes during early infection of wheat spikes by Fusarium graminearum." Molecular Plant Microbe Interaction. 13: 159 169

Pritsch, C., Vance, C. P., Bushnell, W. R., Somers, D. A., Hohn, T. M. and Muehlbauer, G. J. (2001). "Systemic expression of defense response genes in wheat spikes as a response to Fusarium graminearum infection." Physiological and Molecular Plant Pathology. 58: 1 12

Ramamoorthy, V.; Raguchander, T.; Samiyappan, R. (2002). Induction of defense-related proteins in tomato roots treated with Pseudomonas fluorescens Pf1 and Fusarium oxysporum $f$. sp. lycopersici. Plant and Soil. 239: 55-68.

Rasumussen, U., Bojsen, K and collinge, D.B. (1992). Cloning and characterization of a pathogen induced chitinase in Brassica napus. Plant.Mol.Biol., 20:277-287.

Reissigs, J.L.; Strominger, J.L. and Lealoir, L.F. (1955).A modified colorimetric methods for determination of n-acetyl amino sugars. J.Biol.Chem. 217:959966

Saikia, R.; Singh, B.P.; Rakesh Kumar and Arora, D.K (2005). Detection of pathogenesis-related proteins-chitinase and $\beta-1, \quad 3$-glucanase in induced chickpea. Current Science. 89: 659-663.

Samac, D.A., Hironaka, C.M., Yallaly, P.E and Shah, D.M. (1990). Isolation and characterization of the gene encoding basic and acidic endo chitinase in Arabidopsis thaliana. Plant. Physiol.93:907-914.

Schlumbaum, A.., Mauch, F., Vogeli,U and Boller T. (1986). Plant chitinase are potent inhibitors of fungal growth. Nature., 324:365-367.

Shukla, Y. M (2001). Ph.D dissertation, Submitted at Gujarat Agril. university 
Chapter-3.

Shukla Y.M and K P Suthar (2017) . Alteration in b-1, 3 glucanase and chitinase activity in chickpea varieties infected with Fusarium oxysporum $f$. $s p$. ciceri race 4. Article ID: LR-3671.

Selevendran, R. R. (1985). Development of chemistry and biochemistry of pectic acid and hemicellulose polymers. $J$. Cell Sci. Suppl., 2:51-88.

Thangavelu, R.; Palaniswami, A.; Doraiswamy, $\mathrm{S}$ and Velazhahan, $\mathrm{R}$. (2003). The effect of Pseudomonas fluorescens and Fusarium oxysporum f.sp. cubense on induction of defense enzymes and phenolics in banana. Biologia Plantarum. 46: 107-112.

Vanloon, L. C. and Van Kammen, A. (1970). Polyacrylamide disc electrophoresis of the soluble leaf proteins from Nicotinia tabacum var. Samsun NN changes in proteins constitution after infection with tobacco. Virology, 40:199-201.

Vanloon, L.C. (1985). Plant pathogenesis proteins. Plant Mol.Biol. 4:111-116.

Varshney RK, Thudi M, Roorkiwal M, He W, Upadhyaya HD, Yang W, Bajaj P,
Cubry P, Rathore A, Jian J, Doddamani D, Khan AW, Garg V, Chitikineni A, Xu D, Gaur PM, Singh NP, Chaturvedi SK, Nadigatla GVPR, Krishnamurthy L, Dixit GP, Fikre A, Kimurto PK, Sreeman SM, Bharadwaj C, Tripathi S, Wang J, Lee SH, Edwards D, Polavarapu KKB, Penmetsa RV, Crossa J, Nguyen HT, Siddique KHM, Colmer TD, Sutton T, von Wettberg E, Vigouroux Y, Xu X, Liu X (2019) Resequencing of 429 chickpea accessions from 45 countries provides insights into genome diversity, domestication and agronomic traits. Nat Genet 51:857-864

Vogeli- Lange, R.; R., Hansen-Gehri, A., Boller, T. and Meins, F.Jr. (1988). 119.

Voisey, C.R. and Slusarenko, A.J. (1989). Chitinase m RNA and enzyme activity in Phaseolus vulgaris (L.) increase more rapidly in response to avirulent than to virulent cells of Pseudomonas syringae pv. Phaseolicola. Physiol.Mol.Plant Pathol., 35:403-412.

\section{How to cite this article:}

Rathod, P. J. and Vakharia, D. N. 2020. Inbuilt Characteristics of Hydrolytic Enzymes Activities in Root Tissues of Chickpea (Cicer arietinum L) Cultivars of Gujarat against Fusarium Wilt (Fusarium oxysporium f.spp ciceri) Disease Infection. Int.J.Curr.Microbiol.App.Sci. 9(06): 1824-1834. doi: https://doi.org/10.20546/ijcmas.2020.906.227 